\title{
Commentary: Deformation and Fault Propagation at the Lateral Termination of a Subduction Zone: The Alfeo Fault System in the Calabrian Arc, Southern Italy
}

\author{
Andrea Argnani * \\ ISMAR-CNR, Bologna, Italy
}

Keywords: lithospheric tear fault, seismic stratigraphy, Calabrian subduction, Ionian Sea, Italy

A Commentary on

Deformation and Fault Propagation at the Lateral Termination of a Subduction Zone: The Alfeo Fault System in the Calabrian Arc, Southern Italy

by Maesano, F. E., Tiberti, M. M., and Basili R. (2020). Front. Earth Sci. 8:107. doi: 10.3389/feart.2020. 00107

\section{OPEN ACCESS}

Edited by: Alexander Cruden, Monash University, Australia

Reviewed by:

Stephane Dominguez, Géosciences Montpellier, France

${ }^{*}$ Correspondence: Andrea Argnani andrea.argnani@ismar.cnr.it

Specialty section: This article was submitted to Structural Geology and Tectonics,

a section of the journal

Frontiers in Earth Science

Received: 03 September 2020 Accepted: 09 November 2020

Published: 26 November 2020

Citation:

Argnani A (2020) Commentary: Deformation and Fault Propagation at

the Lateral Termination of a

Subduction Zone: The Alfeo Fault

System in the Calabrian Arc,

Southern Italy.

Front. Earth Sci. 8:602506.

doi: 10.3389/feart.2020.602506

\section{INTRODUCTION}

Maesano et al. (2020) (MTB hereafter) address the occurrence of a lithospheric tear in the western Ionian Sea, an highly debated issue, arguing that the Alfeo Fault system (AFS) is the "lateral termination of the subduction zone." The new data presented are of good quality and contribute to the geological understanding of the region. Nevertheless, some interesting issues in MTB's paper deserve to be discussed and are briefly tackled below.

\section{DISCUSSION}

\section{Previous Literature}

In more than one occasion the use of the literature is inappropriate and selective. This statement of MTB “. . . observations contradict the interpretation of the Malta Escarpment as a major Quaternary fault like so far proposed (e.g., ...; Argnani et al., 2012).” erroneously reports the content of Argnani et al., 2012 that clearly state how recent tectonic activity along the Malta Escarpment occurs only north of Siracusa, i.e., north of profile A of MTB. The tectonics of the Malta Escarpment was specifically addressed by Argnani and Bonazzi (2005) on the basis of a large set of seismic profiles purposely acquired; a paper that has regrettably been ignored by MTB.

In order to support that AFS is the lithospheric boundary of the Calabrian subduction, MTB state that " evidence of syn-sedimentary Pliocene-Holocene tectonic activity is found only in the SSTBs located above the AFS." MTB missed that a large and active extensional basin is present along the Malta Escarpment north of Siracusa (Argnani and Bonazzi, 2005; Figure 1), with a sedimentary fill that is thicker than that of the Shallow Syn-Tectonic Basins (SSTBs). 


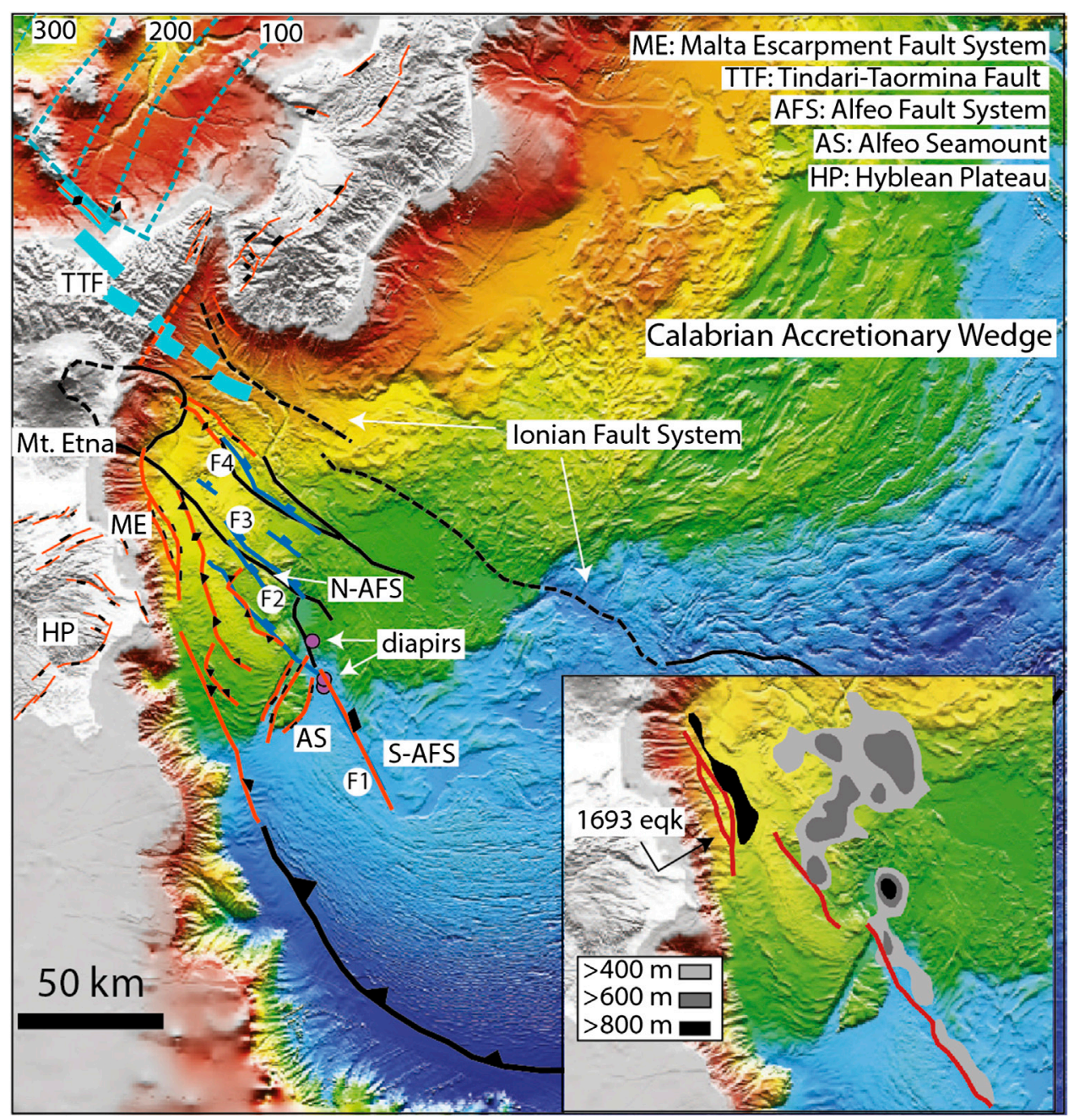

FIGURE 1 | Simplified tectonic map of the western lonian region, showing a compilation of the main structural features. Faults are from Argnani, 2014 (in red), and from Gutscher et al., 2017 (in black); the deep faults (F1 to F4) of the AFS are from MTB (dark blue); note that F1 was already known from previous literature and was mapped in Argnani, 2014. Lines with rectangles: extensional faults; lines with triangles: thrusts and reverse faults, lines with diamonds: anticlines. The red dashed line in the Messina Strait represents a flexure. The North and South branches of the AFS are after Gutscher et al. (2017). The diapirs mapped by MTB are also indicated.

Thick, dashed light blue lines indicate the trace of the Tindari-Taormina Fault (after Barreca et al., 2019). The dashed light blue lines are depth contours in km of the top of the subducted slab in the Tyrrhenian region (from Frepoli et al., 1996). The structures are superimposed on the morpho-bathymetry of Gutscher et al. (2017). The map in the inset shows the thickness of the sedimentary basins along the AFS (from MTB) and the Malta Escarpment (from Argnani and Bonazzi 2005). Basin-bounding faults are in red, and the possible fault responsible for the 1693 earthquake and tsunami is also indicated (after Argnani et al., 2012).

\section{Northern Extent of Alfeo Fault System}

The AFS is represented by a single fault south of the Alfeo Smt. whereas north of the Alfeo Smt. it broadens in a belt ca. $25 \mathrm{~km}$ wide, composed of 4 faults (Figure 1). The northern fault (F4) is interpreted as connected to the Tindari-Taormina Fault (TTF). Unlike F4, that is a deep fault decoupled from the surface, the TTF offshore extent is traced from shallow seismics (Barreca et al., 2019), and is interpreted to be connected to the Ionian Fault, being more to the north-east with respect to the AFS. Published seismic profiles (Argnani et al., 2009; Argnani et al., 2013) that cross the TTF and the prolongation of F4 show no sign of significant deformation in the upper sedimentary unit. It is therefore not clear how MTB can support a connection between AFS and TTF.

\section{Shallow Syn-Tectonic Basins and Age Attribution}

MTB assume a close relationship between faulting along the deep AFS and origin of the SSTBs: dating the onset of a basin in a specific segment allows to assign an age to the activity of the deep faults. The lack of a direct linkage between the deep AFS and the SSTBs, however, leaves room to uncertainty. Moreover, because sedimentary basins are basically only along F1 (Figure 1, inset), the age of the other faults (F2 to F4) can only be inferred assuming a simultaneous activation.

The inferred southward propagation of the deep AFS is based on the younger age of the basins south of the Alfeo Smt. and on an early synclinal basin, as the one in profile F, supposed to precede 
the onset of the basin-bounding fault. However, where the basinbounding fault is present the stratigraphic architecture of the basin fill shows no evidence of an early syncline, questioning fault propagation. Regrettably, the poor quality of the seismic reproduction does not allow to evaluate the stratigraphic argument that led MTB to assign a younger age $(1.3 \mathrm{Ma})$ to the SSTB in profile E with respect to profile A (2.6 Ma); along the AFS the stratigraphy of the SSTBs looks pretty much the same.

The SSTB stratigraphy of profile A (MTB, Figure 9) can be interpreted in a different way. The units on either side of the basin show different seismic facies. On the footwall (position A1) U1 is mostly composed by a facies with moderate-high amplitude, good continuity sub-parallel reflections that resembles U1c within the basin. On the hangingwall (position A2) U1 shows reflections with variable amplitude and poor continuity that resemble U1a within the basin. MTB interpret U1b as made by turbidites, however the chaotic seismic facies is more suggestive of a mass flow deposit.

It seems that sediment compaction has not been considered by MTB. The thickness of unit U1a at location Bmin (MTB, Figure 9) should be $135 \mathrm{~m}$ (sedimentation rate of $0.05 \mathrm{~mm} / \mathrm{yr}$ for 2.7 Myr). However, the load of about $700 \mathrm{~m}$ of sediments can cause a substantial compaction, with a restored thickness of up to 180-200 m, using general depth-compaction relationships (e.g., Sclater and Christie, 1980). This greatly affects the inferred age of the top of U1a, which is taken as the age of onset of the basin. For instance, taking a decompacted thickness of $180 \mathrm{~m}$ and assuming an average sedimentation rate of $0.05 \mathrm{~mm}$ /year, the top of U1a is 1.7 Ma old. In summary, age attribution is poorly constrained because of several uncertainties, and in turn this undermines the inferred rates of fault throw and fault propagation.

\section{Under-Explored Tectonic Issues}

Some issues in MTB interpretation are relevant for the tectonics of the Calabrian accretionary wedge (CAW) and should have deserved more attention.

MTB say that their interpretation agrees with that of Dellong et al., 2018, apart from some "essential differences." Dellong et al. present refraction data that do not directly support the location of a STEP fault; they argue that the AFS is more likely than the Ionian Fault system as a STEP fault, following the work of Gutscher et al. (2016); Gutscher et al. (2017). Gutscher et al. suggest that the SSTBs are originated by strike-slip faults directly linked to the lithospheric tear, and this differs from the interpretation of MTB, where the normal faults affecting the SSTB are decoupled from the normal faults offsetting the

\section{REFERENCES}

Argnani, A. (2014). Reply to comment on the article "propagation of a lithospheric tear fault (STEP) through the western boundary of the Calabrian accretionary wedge offshore eastern Sicily (Southern Italy)" by Gallais et al., 2013 Tectonophysics. Tectonophysics 610, 195-199. doi:10.1016/j.tecto.2013.06.035 Argnani, A., and Bonazzi, C. (2005). Malta escarpment fault zone offshore eastern Sicily: pliocene-quaternary tectonic evolution based on new multichannel seismic data. Tectonics 24. doi:10.1029/2004tc001656 basement. Moreover, F4 is much more to the north-east with respect to the AFS defined by Gutscher et al., which is less wide (Figure 1). To sum up, the width of the AFS, the nature of basement faults, and the origin of the SSTB are different from what described by Gutscher et al. The implications of these major differences have not been discussed in any extent.

The debated occurrence of serpentinite diapirism in the western CAW has been suggested by Polonia et al. (2017). MTB map some diapirs which are in the same position as those of Polonia et al. (Figure 1). Although this issue is relevant for the tectonics of the CAW, MTB do not comment on it, nor they describe these diapirs in any detail. It would be interesting to know whether the diapirs root into the lower plate (as inferred by Polonia et al.) or just develop within the AW.

\section{Natural Hazard Implications}

The decoupling between the deep AFS and the faults bounding the SSTBs implies that the AFS has little if any capability to generate tsunamis, unlike what suggested by some authors (e.g., Polonia et al., 2012; Gutscher et al., 2016). On the other hand, it strengthens the proposal of Argnani et al. (2012) that the earthquake and tsunami of 1693 originated along the Malta Escarpment fault system (Figure 1, inset).

\section{AUTHOR CONTRIBUTIONS}

The author confirms being the sole contributor of this work and has approved it for publication.

\section{FUNDING}

This work received financial support from the Italian Ministry of Economic Development, Directorate General for Safety-National Mining Office for Hydrocarbons and Georesources (DGS-UNMIG) under the umbrella of the offshore safety network "Clypea"-Innovation Network for Future Energy.

\section{ACKNOWLEDGMENTS}

A sincere thanks to the many colleagues that worked with me in the last 20 years on several geological and geophysical aspects of the western Ionian region, broadening my perspective.

Argnani, A., Armigliato, A., Pagnoni, G., Zaniboni, F., Tinti, S., and Bonazzi, C. (2012). Active tectonics along the submarine slope of south-eastern Sicily and the source of the 11 January 1693 earthquake and tsunami. Nat. Hazards Earth Syst. Sci. 12, 1311-1319. doi:10.5194/nhess-12-1311-2012

Argnani, A., Brancolini, G., Bonazzi, C., Rovere, M., Accaino, F., Zgur, F., et al. (2009). The results of the Taormina 2006 seismic survey: possible implications for active tectonics in the Messina Straits. Tectonophysics 476, 159-169. doi:10. 1016/j.tecto.2008.10.029

Argnani, A., Mazzarini, F., Bonazzi, C., Bisson, M., and Isola, I. (2013). The deformation offshore of Mount Etna as imaged by multichannel seismic 
reflection profiles. J. Volcanol. Geotherm. Res. 251, 50-64. doi:10.1016/j. jvolgeores.2012.04.016

Barreca, G., Scarfi, L., Gross, F., Monaco, C., and De Guidi, G. (2019). Fault pattern and seismotectonic potential at the south-western edge of the Ionian Subduction system (southern Italy): new field and geophysical constraints. Tectonophysics 761, 31-45. doi:10.1016/j.tecto.2019.04.020

Dellong, D., Klingelhoefer, F., Kopp, H., Graindorge, D., Margheriti, L., Moretti, M., et al. (2018). Crustal structure of the Ionian basin and Eastern Sicily margin: results from a wide-angle seismic survey. J. Geophys. Res. B: Solid Earth 123, 2090-2114. doi:10.1002/2017jb015312

Frepoli, A., Selvaggi, G., Chiarabba, C., and Amato, A. (1996). State of stress in the southern Tyrrhenian subduction zone from fault-plane solutions. Geophys. J. Int. 125 (3), 879-891. doi:10.1111/j.1365-246X.1996.tb06031.x

Gutscher, M.-A., Dominguez, S., Mercier de Lepinay, B., Pinheiro, L., Gallais, F., Babonneau, N., et al. (2016). Tectonic expression of an active slab tear from high-resolution seismic and bathymetric data offshore Sicily (Ionian Sea). Tectonics 35, 1. doi:10.1002/2015tc003898

Gutscher, M.-A., Kopp, H., Krastel, S., Bohrmann, G., Garlan, T., Zaragosi, S., et al. (2017). Active tectonics of the Calabrian subduction revealed by new multi-beam bathymetric data and high-resolution seismic profiles in the Ionian Sea (Central Mediterranean). Earth Planet. Sci. Lett. 461, 61-72. doi:10.1016/j.epsl.2016.12.020

Maesano, F. E., Tiberti, M. M., and Basili, R. (2020). Deformation and fault propagation at the lateral termination of a subduction zone: the Alfeo fault system in the Calabrian Arc, southern Italy. Front. Earth Sci. 8, 107. doi:10. 3389/feart.2020.00107

Polonia, A., Torelli, L., Gasperini, L., and Mussoni, P. (2012). Active faults and historical earthquakes in the Messina Straits area (Ionian Sea). Nat. Hazards Earth Syst. Sci. 12, 2311-2328. doi:10.5194/nhess-12-2311-2012

Polonia, A., Torelli, L., Gasperini, L., Cocchi, L., Muccini, F., Bonatti, E., et al. (2017). Lower plate serpentinite diapirism in the Calabrian Arc subduction complex. Nat. Commun. 8, 2172 doi:10.1038/s41467-01702273-x

Sclater, J. G., and Christie, P. A. F. (1980). Continental stretching: an explanation of the post-mid-cretaceous subsidence of the central North Sea basin. J. Geophys. Res. 85, 3711-3739. doi:10.1029/jb085ib07p03711

Conflict of Interest: The authors declare that the research was conducted in the absence of any commercial or financial relationships that could be construed as a potential conflict of interest.

Copyright $\odot 2020$ Argnani. This is an open-access article distributed under the terms of the Creative Commons Attribution License (CC BY). The use, distribution or reproduction in other forums is permitted, provided the original author(s) and the copyright owner(s) are credited and that the original publication in this journal is cited, in accordance with accepted academic practice. No use, distribution or reproduction is permitted which does not comply with these terms. 